\title{
THE ROLE OF ROAD TRAFFIC AND TRANSPORTATION FORUM IN THE REGIONAL ROAD GRANTS PROGRAM
}

\author{
Dewi Atikah ${ }^{1}$ \\ ${ }^{1}$ Road and Bridge Engineering, East Java Provincial Road and Bridge Public Works Office, \\ Gayung Kebonsari 167 Surabaya, Indonesia \\ d3wi.atikah@gmail.com
}

\begin{abstract}
.
The Road Traffic and Transportation Forum (FLLAJ) is a prerequisite for the Regional Road Grant Program to increase community involvement and transparency of the quality of road maintenance work, through cooperation and participation of all stakeholders. FLLAJ'S duties include receiving input or complaints from the public regarding roads, traffic and road transport. The purpose of writing this paper is to determine the number of community complaints that have been submitted through the FLLAJ website and whether the problems with these complaints can be resolved. The problem limitation in this study is the Provincial FLLAJ, namely the Bangka Belitung Islands Province, West Nusa Tenggara Province, and East Java Provinces. Complaints that are entered through the respective FLLAJ's website, not through other social media which cannot be accessed by the public freely. The method used in this analysis is descriptive method. The result of this analysis is that the most complaints came from West Nusa Tenggara Province with a total of 81 complaints. As stated on the website, no one has uploaded any follow-up on these complaints, so for the second problem, it cannot be analyzed whether the problem has been can be resolved or not, because there is no detailed information regarding the resolution of the complaint. In conclusion, the FLLAJ plays a role in the Regional Road Grant Program, with many complaints being made on the FLLAJ websites of each province.
\end{abstract}

Keywords: FLLAJ, complaints, follow-up, role

\section{Introduction}

The establishment of the Road Traffic and Transportation Forum (FLLAJ) is a prerequisite for this Regional Road Grant Program. The PHJD (Regional Road Grant Program) aims to increase community involvement and transparency for the quality of road maintenance works, through cooperation and participation of all stakeholders [1]. The implementation of road traffic and transportation is cross-sector in nature and must be carried out in a coordinated manner by the supervisors and the stakeholders. In order to overcome a very complex problem, an integrated system is needed in the Road Traffic and Transportation Forum. The Road Traffic and Transportation Forum (FLLAJ) as stated in the Government Regulation of the Republic of Indonesia Number 37 of 2011 [3] concerning the Road Traffic and Transportation Forum is a vehicle for coordination between traffic and road transport administering agencies. The Road Traffic and Transportation Forum functions as a vehicle for synergizing the main tasks and functions of each road traffic and transportation operator in the operation of road traffic and transportation. The Road and Transport Traffic Forum (FLLAJ) is an AD HOC agency that functions as a vehicle to synergize the main tasks 
and functions of each traffic and road transport agency in order to analyze problems, bridge, find solutions and improve service quality, and not as an apparatus law enforcer.

The FLLAJ, provides information on road traffic and transport to the community, receives input from the community on road, traffic and road transport services, and follows up on these inputs through coordination with all relevant stakeholders [9].

\section{Materials and Methods}

In PMM Amendment 2 [1], the establishment and enhancement of the FLLAJ role as an effort to encourage community involvement and improve gender equality. The Ministry of Transportation as the technical supervisor of the transportation sector, including the Road Transport Traffic Forum (FLLAJ), both at the central and regional levels, which functions to coordinate all matters related to transportation safety with all related work units.

The role of the Road Transportation Traffic Forum (FLLAJ) in the PHJD Program is as a vehicle to synergize the main tasks and functions of each road traffic and transportation operator in the operation of road traffic and transportation. Based on Government Regulation no. 37 of 2011 [3] include:

1) As coordination between administering agencies requiring integration in planning, organizing and resolving road traffic and transportation problems.

2) As an accelerator in accommodating information (suggestions or complaints from the public) regarding the implementation of road traffic and transportation.

3) As part of the proportional settlement process in solving problems in traffic administration and road transportation

PMM Amendment 2 [1] concerning the establishment of FLLAJ:

1) Governor / Regent Decree regarding FLLAJ and FLLAJ Working Group (Pokja) with a composition of 50\%: 50\% elements of Provincial / Regency Government and nongovernment (including academics, community / customary / religious leaders, community groups observing roads / service associations transportation providers, and representatives of public utility owners) with a streamlined and effective number of personnel were authorized. Non-governmental Head of Working Group / Pokja FLLAJ;

2) Secretariat

The FLLAJ secretariat which is supported by adequate staff (at least 1 expert / senior staff and 1 support staff) is operational

In accordance with the PMM, FLLAJ duties include:

1) To coordinate between agencies.

2) Hold monthly and quarterly meetings.

3) To be actively involved in the development planning (musrembang) activities in the transportation sector.

4) Receiving input / complaints from the public regarding roads, traffic and road transportation. 
5) Provide input and recommendations on the regional road grant program

6) Providing information to the public related to roads, traffic and road transportation.

7) Conduct public consultations for every activity that has a broad impact on the community.

8) Monitoring and evaluating and providing recommendations on activities related to traffic administration and road transportation.

9) The FLLAJ website displays 40 project-related data (1 package for each KDP) referring to the construction sector transparency (cost) guide and disseminates this to the community during public consultations

Actually, with the existence of the Regional Road Grant Program, there is a synergy between stakeholders. Because the roads handled lead to the same destination, for example Mount Bromo, East Java. The Mount Bromo Integrated Tourism Area is included in the KSPN BTS (Bromo Tengger Semeru National Tourism Strategic Area). To go to Mount Bromo can be reached from several routes, such as from the direction of Pasuruan Regency, Probolinggo Regency, Malang Regency for the corridor road. Meanwhile, non-corridor roads can be reached via the route in Lumajang Regency. The route to Mount Bromo in Pasuruan Regency involves two government agencies, namely the East Java Provincial Government and the Pasuruan Regency Government. Incidentally, the roads are also directly adjacent, so road handling is integrated. The concept promoted by PHJD in the form of a synergy between several elements is very good to apply. The existence of the FLLAJ is a link between these elements.

Problems:

1. Number of community complaints that have been submitted through the FLLAJ website?

2. Was the problem that was complained about successfully resolved?

Restricting the problem:

The FLLAJ studied was the Provincial FLLAJ and selected three provinces with large budget values, namely the Province of Bangka Belitung Islands, West Nusa Tenggara Province, and East Java Provinces. The analysis of the number of complaints is recapitulated based on the number of complaints that have been submitted through the website of each FLLAJ, not through other social media which cannot be accessed by the public freely.

The method used in this analysis is descriptive method. According to [8], the method of qualitative descriptive analysis is to analyze, describe, and summarize various conditions, situations from various data collected in the form of interviews or observations regarding the problems under study that occur in the field.

A study cannot be separated from data. Data collection techniques are a method used by a researcher to collect the data needed in research [7]. The data in this study were collected from the selected FLLAJ's website, as stated in the problem restriction.

\section{Results and Discussion}

One form of democratic practice in public services is to provide opportunities for the public to submit complaints or complaints when the service they receive does not match expectations or does not match what the service provider promises [2]. 
The government in this case is a person who is mandated by the community as a service provider to improve its services. It is necessary to make various efforts including handling complaints (complaints) from the community [10].

Information disclosure and the obligation to collect public complaints require that FLLAJ has its own website. Here the authors compare between the Provincial FLLAJ websites, because the Provincial Road Traffic and Transportation Forum handles more complex problems and on average the location of the FLLAJ head office is not in one city with the location of road works. In addition, the author wants to know the level of FLLAJ participation in construction work.

The existence of social media belonging to the Public Works Agency of Bina Marga, East Java Province also reduces the number of complaints to the FLLAJ. As in the construction work in East Java, the roads being worked are of course scattered, not in the same city with the FLLAJ head office, so of course there are many problems that the FLLAJ cannot record.

In PMM [1], regarding Complaints Handling, Reporting Aspects, there must be a safe and effective mechanism to report allegations or acts of corruption related to the PHJD Program:

1. Public complaints are submitted to the Regional Information Center and FLLAJ which can be done in writing (letters, sms, etc.) and not in writing (direct reports, telephone etc.)

2. All reports must be followed up within 7 working days and the confidentiality of the reporter is guaranteed

3. All incoming reports will be recorded in a data center equipped with a reference number and the progress of the follow-up

Follow-up on complaints reported by the public must be submitted to the related party at the latest within 7 working days from the time the complaint was received.

The following is a report on public complaints at the Land Transport Traffic Forum for the Province of Bangka Belitung Islands [4]:

Table 1. Complain in the Province of Bangka Belitung Islands

\begin{tabular}{|c|l|l|l|l|}
\hline No. & \multicolumn{1}{|c|}{ Date } & \multicolumn{1}{|c|}{ Title of Aspiration } & \multicolumn{1}{|c|}{ Sender } & Response Date \\
\hline 1 & $20 / 10 / 20$ & $\begin{array}{l}\text { Related to public transportation } \\
\text { Ahmad Yani Pangkalpinang Road } \\
\text { Intersection Infrastructure }\end{array}$ & $\begin{array}{l}\text { Imran Ropani } \\
\text { Manurung }\end{array}$ & $21 / 10 / 20$ \\
\hline 2 & $20 / 10 / 20$ & Lack of street lighting & Muhammad Rizaldi & $21 / 10 / 20$ \\
\hline 3 & $20 / 10 / 20$ & Road users & Muhammad Ali Akbar & $21 / 10 / 20$ \\
\hline 4 & $20 / 10 / 20$ & Traffic signs & Sutrisno Abdurahman & $21 / 10 / 20$ \\
\hline 5 & $20 / 10 / 20$ & Road markings & Indra osama & $21 / 10 / 20$ \\
\hline 6 & $20 / 10 / 20$ & Public transportation & Rezeki Arini & $21 / 10 / 20$ \\
\hline 7 & $20 / 10 / 20$ & Sidewalk & Agus Putra Pratama & $21 / 10 / 20$ \\
\hline 8 & $20 / 10 / 20$ & The Kerabut Bridge collapses & Arya Wimahesa & $21 / 10 / 20$ \\
\hline 9 & $20 / 10 / 20$ & Public Street Lighting & rozani idris & $21 / 10 / 20$ \\
\hline 10 & $20 / 10 / 20$ & $\begin{array}{l}\text { Reactivation of shielded terminals } \\
\text { Ismi Choiriya }\end{array}$ & $21 / 10 / 20$ \\
\hline 11 & $20 / 10 / 20$ & $\begin{array}{l}\text { The permit stated that the lack of } \\
\text { street lights on several roads in the } \\
\text { city of Sungailiat is expected to be } \\
\text { repaired }\end{array}$ & $\begin{array}{l}\text { Adi Setiawan Nur } \\
\text { Hidayanto }\end{array}$ & $21 / 10 / 20$ \\
\hline 12 & $20 / 10 / 20$ & estimate & Muhammad Rifqi & $21 / 10 / 20$ \\
\hline
\end{tabular}




\begin{tabular}{|c|c|c|c|c|}
\hline No. & Date & Title of Aspiration & Sender & Response Date \\
\hline 13 & $28 / 08 / 20$ & euphoria bicycle & wenny amalia & $28 / 08 / 20$ \\
\hline 14 & $28 / 08 / 20$ & Lighting and convex mirrors & wenny amalia & $28 / 08 / 20$ \\
\hline 15 & $27 / 08 / 20$ & Lack of lighting on the highway & Muhammad arkan faizi & $28 / 08 / 20$ \\
\hline 16 & $27 / 08 / 20$ & $\begin{array}{l}\text { pedestrian and parking facilities on } \\
\text { street }\end{array}$ & $\begin{array}{l}\text { Muhammad Indra } \\
\text { Solihin }\end{array}$ & $28 / 08 / 20$ \\
\hline 17 & $27 / 08 / 20$ & Street lighting & $\begin{array}{l}\text { Muhammad Indra } \\
\text { Solihin }\end{array}$ & $28 / 08 / 20$ \\
\hline 18 & $27 / 08 / 20$ & Broken Car Glass & $\begin{array}{l}\text { Dimas W Dwikatama } \\
\text { Putra }\end{array}$ & $28 / 08 / 20$ \\
\hline 19 & $27 / 08 / 20$ & Public transport management & Nur Ihsan Maulana & $28 / 08 / 20$ \\
\hline 20 & $27 / 08 / 20$ & Public transportation & $\begin{array}{ll}\text { Muhammad Dani } \\
\text { Septiadi }\end{array}$ & $28 / 08 / 20$ \\
\hline 21 & $27 / 08 / 20$ & a single accident & Budi & $28 / 08 / 20$ \\
\hline 22 & $27 / 08 / 20$ & SD 19 a sacred village & Hengki Pranata & $28 / 08 / 20$ \\
\hline 23 & $26 / 08 / 20$ & Fee waiver & nando okta vahrozie & $26 / 08 / 20$ \\
\hline 24 & $02 / 07 / 20$ & financing for rapid test is eliminated & Rosmalawati & $02 / 07 / 20$ \\
\hline 25 & $02 / 07 / 20$ & $\begin{array}{l}\text { Accident of } 1 \text { family in Ketap } \\
\text { Village, Jebus District }\end{array}$ & dwi arya & $02 / 07 / 20$ \\
\hline 26 & $02 / 07 / 20$ & Street lights on Depati Hamzah street & arina & $02 / 07 / 20$ \\
\hline 27 & $02 / 07 / 20$ & New normal & Dezza Alzamora & $02 / 07 / 20$ \\
\hline 28 & $02 / 07 / 20$ & $\begin{array}{l}\text { Problems regarding the operation of } \\
\text { special rental transportation at the } \\
\text { airport }\end{array}$ & Wenny & $02 / 07 / 20$ \\
\hline 29 & $02 / 07 / 20$ & Public transportation & Krismanto Silaban & $02 / 07 / 20$ \\
\hline 30 & $15 / 03 / 20$ & Public vehicles & Darmawan & $15 / 03 / 20$ \\
\hline 31 & $15 / 03 / 20$ & Street lights & $\begin{array}{ll}\text { Irfan } & \text { Hafidh } \\
\text { Armmawadin } & \\
\end{array}$ & $15 / 03 / 20$ \\
\hline 32 & $15 / 03 / 20$ & $\begin{array}{l}\text { The road terminal infrastructure is } \\
\text { stuck }\end{array}$ & Harrist Arrahman & $15 / 03 / 20$ \\
\hline 33 & $14 / 03 / 20$ & Traffic Signs Losing Meaning & Aditya Wardhana & $15 / 03 / 20$ \\
\hline 34 & $04 / 03 / 20$ & Gold Bridge Accident Handling & $\begin{array}{ll}\text { Yohanes } & \text { Pungkas } \\
\text { Wijoyo } & \\
\end{array}$ & $5 / 03 / 20$ \\
\hline 35 & $24 / 02 / 20$ & Community Accidents & Dedhe & $31 / 03 / 20$ \\
\hline 36 & $24 / 02 / 20$ & $\begin{array}{l}\text { Recommendations worthy of } \\
\text { Andalalin or not yet feasible }\end{array}$ & Nico Juliansyah & $31 / 03 / 20$ \\
\hline 37 & $04 / 09 / 19$ & Public transportation & $\begin{array}{ll}\text { Lukman } & \text { Hakim } \\
\text { Zulfandi }\end{array}$ & $26 / 09 / 19$ \\
\hline 38 & $23 / 07 / 19$ & accident at the fork & Dwi Retno Syarif & $11 / 04 / 19$ \\
\hline 39 & $23 / 07 / 19$ & Street lights & Putri Maryam & $11 / 04 / 19$ \\
\hline 40 & $10 / 07 / 19$ & $\begin{array}{l}\text { Low Level Of Public Compliance } \\
\text { With Traffic }\end{array}$ & septian & $10 / 07 / 19$ \\
\hline 41 & $09 / 07 / 19$ & $\begin{array}{l}\text { Street Light in Pangkalpinang City } \\
\text { has been off }\end{array}$ & Nopriyanto & $10 / 07 / 19$ \\
\hline 42 & $09 / 07 / 19$ & $\begin{array}{l}\text { Many roads in Taman Kota housing } \\
\text { have holes in them }\end{array}$ & Nopriyanto & $10 / 07 / 19$ \\
\hline 43 & $25 / 12 / 14$ & $\begin{array}{l}\text { Nearly Rubuh Bridge in Riau Silip } \\
\text { District }\end{array}$ & Erman Arif, ST & $23 / 07 / 19$ \\
\hline 44 & $25 / 12 / 14$ & $\begin{array}{l}\text { Related to public transportation } \\
\text { Ahmad Yani Pangkalpinang Road } \\
\text { Intersection Infrastructure }\end{array}$ & Erman Arif, ST & $23 / 07 / 19$ \\
\hline
\end{tabular}


From the public complaint report above, the response from the FLLAJ has not shown any improvements to community complaints, only in the form of a response that will be followed up.

The following is a report on public complaints at the West Nusa Tenggara Province Land Transport Traffic Forum [5] :

Table 2. Complain in the West Nusa Tenggara Province

\begin{tabular}{|c|c|c|}
\hline No. & Date & Title of Aspiration \\
\hline 1 & $2020-11-20$ & parking around the street round \\
\hline 2 & $2020-11-16$ & Pruning trees along Jalan Langko and Pejanggik \\
\hline 3 & $2020-10-21$ & puddle \\
\hline 4 & $2020-07-13$ & Online Taxi Legality \\
\hline 5 & $2020-05-11$ & The Traficht Light Complaint \\
\hline 6 & $2020-04-28$ & The Trafight Light doesn't work \\
\hline 7 & $2020-04-24$ & flight schedule \\
\hline 8 & $2020-03-28$ & report \\
\hline 9 & $2020-03-16$ & traffic light interference \\
\hline 10 & $2020-03-15$ & Inputs for CFD Transfers \\
\hline 11 & $2020-02-28$ & Dump Truck Control \\
\hline 12 & 2020-01-06 & the condition of the Narmada National Road \\
\hline 13 & $2019-12-12$ & Jalan Sebasang was badly damaged \\
\hline 14 & $2019-12-11$ & app test \\
\hline 15 & $2019-12-07$ & $\begin{array}{l}\text { Traffic disruption on the National Road Section Narmada - } \\
\text { Central Lombok }\end{array}$ \\
\hline 16 & 2019-12-06 & markers \\
\hline 17 & $2019-11-22$ & trafict ligth \\
\hline 18 & 2019-11-10 & disappointed with Lion Lombok airline \\
\hline 19 & $2019-10-16$ & congestion \\
\hline 20 & $2019-10-15$ & rude, pushy suburban parkers \\
\hline 21 & $2019-10-11$ & PJU EXPECTED \\
\hline 22 & $2019-09-20$ & provide street lighting in teak forest areas \\
\hline 23 & $2019-08-05$ & traffic light \\
\hline 24 & $2019-08-05$ & Billboard \\
\hline 25 & $2019-07-26$ & SIM extension requirements \\
\hline 26 & $2019-07-19$ & $\begin{array}{l}\text { The street lights in front of Pagutan Temple haven't been repaired } \\
\text { yet? }\end{array}$ \\
\hline 27 & 2019-07-16 & strong scent \\
\hline 28 & $2019-07-13$ & danger at Penujak Roundabout \\
\hline 29 & $2019-07-10$ & Simpang Empat Pasar Gunung Sari Lama is totally stuck \\
\hline 30 & $2019-06-17$ & border of west lombok and central lombok \\
\hline 31 & 2019-06-06 & The street lights in Pagutan are off \\
\hline 32 & $2019-05-23$ & The pothole \\
\hline 33 & $2019-05-02$ & park anywhere \\
\hline 34 & 2019-05-01 & Ground transportation services (Bus) \\
\hline 35 & $2019-04-29$ & Severe Wavy Bolong \\
\hline 36 & $2019-04-15$ & crossing tariff adjustments. \\
\hline 37 & $2019-04-15$ & landslide in Lunyuk District \\
\hline 38 & 2019-04-15 & Bridge \\
\hline 39 & $2019-04-15$ & traffight light \\
\hline 40 & $2019-04-15$ & "Not Working " Traffic Signs \\
\hline
\end{tabular}




\begin{tabular}{|c|c|c|}
\hline No. & Date & Title of Aspiration \\
\hline 41 & 2019-04-15 & unsigned intersections \\
\hline 42 & 2019-04-15 & apil \\
\hline 43 & 2019-04-05 & park any vehicle \\
\hline 44 & 2019-04-01 & Roads between provinces have holes \\
\hline 45 & 2019-03-20 & on-street parking \\
\hline 46 & $2019-03-20$ & Congestion on Udayana Street due to on-street parking \\
\hline 47 & 2019-03-09 & $\begin{array}{l}\text { Driver Behavior and Horse Dung in Praya City and its } \\
\text { surroundings }\end{array}$ \\
\hline 48 & 2019-03-05 & bablas sidewalks \\
\hline 49 & $2019-03-05$ & TL Green does not turn on \\
\hline 50 & 2019-03-01 & SAFETY AND COMFORT \\
\hline 51 & $2019-02-26$ & Tree branches blocking traffic flow \\
\hline 52 & $2019-02-25$ & You said that transporting goods. \\
\hline 53 & $2019-02-22$ & The bottom path of the sheet is wavy \\
\hline 54 & 2019-02-05 & water stagnates in swela \\
\hline 55 & 2019-01-30 & tree covered apples \\
\hline 56 & 2019-01-30 & twigs \\
\hline 57 & 2019-01-30 & Salutation for the Transportation Agency of Mataram City \\
\hline 58 & 2019-01-28 & Not comfortable on the highway by Mataram pass \\
\hline 59 & 2019-01-27 & Additional Photos \\
\hline 60 & 2019-01-27 & Potholes that endanger wheel riders 2 \\
\hline 61 & 2019-01-25 & $\begin{array}{l}\text { The community and the government work together to clear the } \\
\text { road due to the wind }\end{array}$ \\
\hline 62 & $2019-01-24$ & PLN cables that run across endanger road users \\
\hline 63 & 2019-01-20 & roads damaged, flooded, potholes \\
\hline 64 & $2019-01-20$ & flooded roads \\
\hline 65 & 2019-01-19 & The road in Rembiga began to break down \\
\hline 66 & 2019-01-16 & $\begin{array}{l}\text { info on illegally parked vehicles without permission from the } \\
\text { Mandalika terminal }\end{array}$ \\
\hline 67 & 2019-01-16 & You can take selfies, but you can also see the terrain, bro ... \\
\hline 68 & 2019-01-15 & Traffic light counts forward not backward \\
\hline 69 & 2019-01-09 & Please open the road beside SD 11 Mataram ... \\
\hline 70 & 2018-12-19 & Traffic Light Simpang 4 PTC is totally dead \\
\hline 71 & $2018-12-19$ & jammed on the road of the cut paok country \\
\hline 72 & $2018-12-17$ & Pasar Tatuh in seketeng - sumbawa besar \\
\hline 73 & $2018-11-21$ & still have not followed up \\
\hline 74 & $2018-11-18$ & road traffic disruption due to construction materials \\
\hline 75 & 2018-11-13 & puddle of underpass \\
\hline 76 & 2018-11-13 & Andalalin \\
\hline 77 & 2018-11-13 & Law enforcement \\
\hline 78 & 2018-11-09 & forward hit back and forth \\
\hline 79 & $2018-10-29$ & pandan duri street lights \\
\hline 80 & $2018-10-27$ & damaged road crossings or connecting bridges \\
\hline 81 & $2018-10-23$ & Utility Installation Permit (PLN Electric Pole) \\
\hline
\end{tabular}

From the public complaint report above, there was no response from the FLLAJ for a follow-up plan. 
The following is a report on public complaints at the East Java Province Land Transport Traffic Forum [6]:

Table 3. Complain in the East Java Province

\begin{tabular}{|c|c|}
\hline No. & Complaint \\
\hline 1 & Damaged roads \\
\hline 2 & The number of potholes in the western part of Ahmad Yani Street \\
\hline 3 & $\begin{array}{l}\text { In Arteri Porong, which has a bridge the road is badly damaged / to the north near the } \\
\text { Suncity bus that goes to Sidoarjo there are also many roads with holes }\end{array}$ \\
\hline 4 & $\begin{array}{l}\text { Pasuruan, many roads are damaged and allowed by the government // even though it is the } \\
\text { rainy season // danger for passing motorists }\end{array}$ \\
\hline 5 & $\begin{array}{l}\text { Probolinggo Pajarakan / there is a puddle // which from the west becomes } 3 \text { lanes // totally } \\
\text { stuck // there must be attention from the government which is in charge of making / } \\
\text { functioning drainage in that location / }\end{array}$ \\
\hline 6 & $\begin{array}{l}\text { 5, many trees fell right at the railroad crossing / after heavy rain and } \\
\text { ere were officers who cut branches / } 2 \text { people }\end{array}$ \\
\hline 7 & $\begin{array}{l}\text { Probolinggo heavy rain // from the Rejoso Weigh Bridge to the east there are } 3 \text { large trees } \\
\text { that have fallen / blocked the road }\end{array}$ \\
\hline 8 & $\begin{array}{l}\text { There is a fallen tree in Bangil Pasuruan // closes the road // many vehicles make a U-turn } \\
\text { // the suggestion is to take the toll road }\end{array}$ \\
\hline 9 & $\begin{array}{l}\text { in front of SMA Negeri If there is a fallen tree that takes up half the way / traffic is made } \\
\text { alternating // there is already an officer at the location / }\end{array}$ \\
\hline 10 & $\begin{array}{l}\text { Ngoro Industri - the eastern ring is busy smoothly // the road is badly damaged in Wates } \\
\text { Negoro and Ngoro Industri // many holes / and takes up the lane // in ketapang there is a } \\
\text { small tree collapsing in the middle of the road }\end{array}$ \\
\hline 11 & $\begin{array}{l}\text { the old porong bridge / crossed by supeltas / it should not be allowed // from the old } \\
\text { porong - japanan / after the bridge has many holes and the road is uneven there is a road to } \\
\text { telocor leading to kec. Jabon is not allowed to pass / there is a fence / but it is not neat so } \\
\text { the motorbike can run }\end{array}$ \\
\hline 12 & $\begin{array}{l}\text { Bungurasih terminal is already open but the bus fleet is not visible yet, on the highway } \\
\text { there are also no AKAP or AKDP buses that pass, The journey from Krian bypass to } \\
\text { Berbek industry is busy. }\end{array}$ \\
\hline 13 & $\begin{array}{l}\text { Queue for tickets, Sim Corner BG junction this morning crowded without social } \\
\text { distancing }\end{array}$ \\
\hline 14 & $\begin{array}{l}\text { This is why the East Java leader did not extend the PSBB, which was expected by many } \\
\text { East Java residents in particular, for example, from the beginning, Alfakir was very } \\
\text { confident and strongly agreed that the East Java leader was said to be "good the best", } \\
\text { remember this if you know ... For example, from the start, only health protocols must be } \\
\text { obeyed during the pandemic. Strongly agree with what Dr Supriyanto Darmorejo said } \\
\text { (sorry if you don't mention the name wrongly), the director of the Iskak Tulungagung } \\
\text { Hospital, which is important, makes the residents always happy even though they are } \\
\text { reactive and otg, so hopefully everyone will recover. As a truck driver I support this. }\end{array}$ \\
\hline 15 & $\begin{array}{l}\text { Early in the morning, I queued (without queue number) for the Psycho Test for SIM } \\
\text { extension, the crowd was already busy even though the office was not yet open - at TEC } \\
\text { (Tunjungan Electronic Center). }\end{array}$ \\
\hline 16 & $\begin{array}{l}\text { \#NEED ATTENTION TO DISHUB. If AKDP bus passengers have to bring a rapid test } \\
\text { letter which is declared negative reactive or not too burdensome for the community. } \\
\text { Meanwhile, the cost of the rapid test is quite expensive for workers whose salaries are } \\
\text { sufficient to eat ... Even though the average bus passengers mostly work in Surabaya and } \\
\text { commute every day and once a week for the Lamongan Bojonegoro area who work in }\end{array}$ \\
\hline
\end{tabular}




\begin{tabular}{|c|l|}
\hline No. & \multicolumn{1}{c|}{ Complaint } \\
\hline 17 & $\begin{array}{l}\text { Surabaya. ** WHEN THE EXPIRITION OF THE RAPID TEST IS ONLY 3 DAYS ... } \\
\text { WHAT IS NOT WEIGHT FOR WE ARE WORKERS. MATUR SUWUN. }\end{array}$ \\
\hline $\begin{array}{l}\text { A crazy person enters the KM 800 Paspro toll road on the lane from Pasuruan to } \\
\text { Probolinggo. Endangering road users, so that related agencies tighten guard at the entrance } \\
\text { and exit tolls and other access. }\end{array}$ \\
\hline 18 & $\begin{array}{l}\text { Manukan kulon jammed 2 directions. Construction on the box culvert project was carried } \\
\text { out in the morning when there was heavy traffic. }\end{array}$ \\
\hline 19 & $\begin{array}{l}\text { Power lines dangled down the middle of the road. Balong bendo direction of Krian market } \\
\text { - in Kemangsen City Kec: Balong-balong endangers road users. }\end{array}$ \\
\hline 20 & $\begin{array}{l}\text { Long traffic jam, the junction of Kejapanan-Gempol-Pasuruan until the arterial road } \\
\text { towards Sidoarjo. }\end{array}$ \\
\hline
\end{tabular}

Table 4. Recapitulation

\begin{tabular}{|c|l|c|}
\hline No. & \multicolumn{1}{|c|}{ Province } & Number of Complain \\
\hline 1 & Kepulauan Bangka Belitung & 44 \\
\hline 2 & Nusa Tenggara Barat & 81 \\
\hline 3 & Jawa Timur & 20 \\
\hline
\end{tabular}

Based on information on the website http://forumllaj-jatim.org/, community complaints have been followed up by the respective agencies.

The following is a recapitulation of the number of complaints:

Based on the table recapitulation of the number of complaints, for the most complaints came from West Nusa Tenggara Province. For the other two provinces, it is possible that complaints are mostly conveyed through other social media such as via Instagram, Twitter or also through letters to the respective DInas or provinces concerned.

For the second problem, for the Province of Bangka Belitung Islands, the response given on the website is that the complaint will be processed or followed up immediately. Meanwhile in West Nusa Tenggara Province, there is no information on the website regarding the response to the complaint. Meanwhile, in East Java Province, the response on the website is that all complaints have been distributed to the relevant agencies.

Based on PMM [1], public complaint service reports including gender classification by means of social media, telephone, application, SMS or other means have been followed up by at least $40 \%$ in Year I stage II, $50 \%$ in Year I stage III, $60 \%$ in Year II stage I , 70\% in Year II stage II, $80 \%$ in Year II stage III, $90 \%$ in Year III of the number of complaints, and have been published on the FLLAJ website;

In accordance with the provisions in PMM, the report must be followed up and published on the website again. Of the three provinces, no one has uploaded any follow-up actions to these complaints.

\section{Conclusions and Suggestions}

1. Based on the table recapitulation of the number of complaints, the highest number of complaints came from West Nusa Tenggara Province with the number of complaints as many as 81 . For the other two provinces, it may be that complaints are mostly conveyed through 
other social media such as via Instagram, Twitter or also through letters to the respective Dinas or the province concerned.

2. As stated on the website, of the three provinces, no one has uploaded any follow-up actions to these complaints. While the provisions in PMM, the report must be followed up and published on the website again, so that for the second problem, it cannot be analyzed whether the problem has been resolved or not, because there is no detailed information regarding the resolution of the complaint.

Based on the description above, it can be concluded that, FLLAJ plays a role in the Regional Road Grant Program, with many complaints being entered on the FLLAJ website of each province. Further suggestions, in accordance with the requirements in PMM, that the results of the follow-up are also uploaded on an open source website, so that they can be accessed freely by the public.

\section{REFERENCES}

[1] A. Firmanti, Amandemen 2 Januari 2020 Manual Manejemen Program (Program Management Manual/PMM) Program Hibah Jalan Daerah. Jakarta: Kementrian Pekerjaan Umum dan Perumahan Rakyat, 2020.

[2] D. A. Negara, "Laporan Kajian Manajemen Pengaduan Masyarakat Dalam Pelayanan Publik," Jakarta, 2010.

[3] Peraturan Pemerintah nomor 37 tahun 2011 tentang Forum Lalu Lintas Dan Angkutan Jalan. .

[4] "Laporan Masyarakat." http://fllaj.babelprov.go.id.

[5] “Aspirasi dan Pelaporan.” http://fllaj.ntbprov.go.id/.

[6] "Data Keluhan Masyarakat." http://forumllaj-jatim.org.

[7] N. Sujana, Menyusun Karya Tulis Ilmiah Untuk Memperoleh Angka Kredit. Bandung: Sinar Baru Algensindo, 2002.

[8] I. M. Winartha, Pedoman Penulisan Usulan Penelitian, Skripsi dan Tesis. Yogyakarta: Andi, 2006.

[9] “FLLAJ." http://spjd.binamarga.pu.go.id (accessed Jan. 13, 2021).

[10] Wiyanto, "Pengelolaan Komplain (Keluhan) Masyarakat dalam Mewujudkan Tata Pamong yang Baik (Good Governance) di Kota Semarang,” Semarang, 2011. 